\title{
Human Machine Interface Visual Basic Arduino Untuk Dc - DC converter Type Buck
}

\author{
Mohammed Abdul Aziz Al-Haqeem 1 , Aswardi 2 \\ 1,2 Jurusan Teknik Elektro, Fakultas Teknik, Universitas Negeri Padang \\ Jl. Prof. Dr. Hamka, Air Tawar Padang, 35132, Indonesia \\ abdulaziz24139@gmail.com 1 , \\ aswardi@ft.unp.ac.id 2
}

\begin{abstract}
In an era of rapidly developing technology, the use of power electronics is increasingly being used, such as for motor control and others. To support all of that, of course also accompanied by interfacing methods that make it easier for users to use power electronic devices such as a buck converter. Interfacing is meant here is to adjust the output of the buck converter by using interfacing on a personal computer as well as monitoring it. Buck converter is a type of dc-dc converter which functions to change the output output voltage to be smaller than the input output voltage. Monitoring design uses Visual Basic in making interfacing, this is done because of the ease of communication between Visual Basic and Arduino. The control method uses the duty cycle setting given from Visual Basic to Arduino. By regulating the duty cycle, the output voltage will vary. Based on the test results, by increasing the duty cycle, the output voltage from the buck converter will be smaller. The measurement results of the buck converter at the input voltage of 24 volts and duty of 15.97 produce an output voltage of 19.5 while the duty cycle of 34.57 produces a voltage of 13.9 .
\end{abstract}

Key words: buck converter, dc-dc converter, duty cycle, interface, visual basic

\begin{abstract}
Abstrak - Pada era teknologi yang semakin berkembang pesat, penggunaan elektronika daya semakin banyak digunakan seperti untuk penggontrolan motor dan lain - lain. Untuk mendukung semua itu tentu juga di iringi dengan metode metode interfacing yang memudahkan user dalam penggunaaan alat - alat elektronika daya seperti contohnya buck conveter. Interfacing yang di maksud disini adalah dengan melakukan pengaturan keluaran buck converter dengan menggunakan interfacing pada personal computer sekaligus memonitoringnya. Buck converter adalah jenis dc-dc converter yang berfungsi untuk mengubah keluaran tegangan output lebh kecil dibandingkan dengan tegangan keluaran input. Perancangan monitoring menggunakan visual basic dalam pembuatan interfacing, hal ini dilakukan karena kemudahan komunikasi antara visual basic dengan arduino. Metode pengontrolan menggunakan pengaturan duty cycle yang diberikan dari visual basic ke arduino. Dengan mengatur duty cycle, maka tegangan yang dkeluarkan pun akan berubah-ubah. Berdasarkan hasil pengujiaan, maka dengan memperbesar duty cycle maka keluaran tegangan dari buck converter akan semakin kecil, Dengan hasil pengukuran buck converter pada input tegangan 24 volt dan duty 15.97 menghasilkan tegangan keluaran sebesar 19,5 sedangkan pada duty cycle 34.57 menghasilkan tegangan sebesar 13.9.
\end{abstract}

Kata kunci: buck converter, dc-dc converter, duty cycle, interface, visual basic

\section{Pendahuluan}

Pada era teknologi yang semakin berkembang pesat ini, penggunaan elektronika daya semakin meluas dan telah menjadi bagian yang sangat penting pada berbagai bidang. Mulai dari skala kecil seperti untuk kebutuhan rumah tangga hingga kebutuhan skala besar sebagai sumber energi bagi industri. Pembangkit-pembangkit tenaga listrik yang menghasilkan energi listrik pun harus sesuai dengan standar kelistrikan yang dibutuhkan beban. Standar tegangan dan frekuensi merupakan bagian yang harus diperhatikan. Untuk standar tegangan, ada dua jenis tegangan yang biasa digunakan untuk berbagai keperluan, yaitu tegangan bolak-balik atau disebut juga dengan alternating current (ac) dan tegangan searah atau direct current $(\mathrm{dc})[1]$.
Dalam bidang elektronika daya telah banyak teknologi yang berkembang untuk menghasilkan ketersediaan suplai tegangan searah (dc), dimana keluaran dari tegangan searah (dc) ini bisa diubah-ubah menjadi lebih kecil dan lebih besar. Proses konversi tegangan searah ini dikenal sebagai DC Chopper [2]-[3]. Pada penerapannya DC Chopper bisa memungkinkan suatu sumber penghasil tegangan searah seperti baterai dapat dirubah keluarannya menjadi lebih besar agar bisa dimanfaatkan untuk berbagai perangkat elektronika sesuai kebutuhan[4]. Sesuai dengan tegangan keluaran yang dihasilkan, konverter dc-dc bisa dibagi atas konverter buck untuk memperoleh tegangan yang lebih kecil dari tegangan masukkan, konverter boost untuk memperoleh tegangan keluaran yang lebih besar dari tegangan masukkan dan konverter buck-boost yang mampu menaikkan dan menurunkan tegangan sehingga tegangan keluarannya bisa lebih kecil dan lebih besar dari 
tegangan masukkan [5]-[6]. Pada konverter dc-dc ini terdapat dua komponen filter yaitu induktor dan kapasitor yang bertugas memperhalus tegangan dan arus keluaran[7].

Pada perancangan alat ini dibuat sebuah buck converter yang gunanya untuk menurunkan tegangan keluaran berdasarkan nilai yang kita inginkan. Untuk mengatur tegangan keluaran dari buck converter ini dibutuhkan sebuah controller. Penerapan dari metode kontrol ini membutuhkan perangkat mikrokontroller. Beberapa mikrokontroller yang telah diterapkan untuk konverter buck antara lain miktokontroller Atmega[8] dan Arduino[9]-[10]. Mikrokontroler yang digunakan untuk konverter buck dalam penelitian adalah board arduino uno. Pemilihan mikrokontroler ini dikarenakan penggunaannya lebih mudah. Biasanya arduino ini diprogram dengan software Arduino Integrated Developtment Enviroenment (IDE). Dalam pengaplikasiannya mikrokontroller dapat digunakan sebagai pembangkit sinyal PWM yang dapat mengatur nilai tegangan keluaran dari sebuah rangkaian buckconverter. Untuk memberi pulsa pulsa (Pulse Width Modulation/PWM) ke buck converter yang nilai dutty cylenya diatur tetap maka digunakan mikrokontroller Arduino Uno.

Mikrokontroller Arduino ini nantinya akan dihubungkan pada sebuah interface (PC) untuk membantu mengatur dan memonitoring nilai yang akan di inputkan pada Arduino. Interface ini dapat mengontrol besar duty cycle dan dapat melihat berapa nilai tegangan keluaran maupun tegangan masukan pada rangkaian buck converter. Maka dari itu digunakan interface menggunakan PC (Personal computer) dengan software Visual Basic Studio.

\section{Metode}

Penelitian ini memonitoring dan controlling buck converter dengan interfacing, maksudnya melakukan pengaturan keluaran buck converter dengan menggunakan interfacing pada personal computer sekaligus memonitoringnya. Untuk mendapatkan tegangan dc yang bervariasi. Konverter buck dirancang dengan tegangan input 24 volt. Penelitian ini dijabarkan pada blok diagram.

\section{DC-DC Converter}

"Dc-dc converters are power electronic circuits that convert a $d c$ voltage to a different dc voltage level, often providing a regulated output"[11]. Pada dc-dc konverter, tegangan keluaran rata-rata harus diatur agar sesuai dengan yang diinginkan, meskipun terkadang tegangan input dan tegangan output berubah-rubah. Dc-dc konverter mode pensaklaran menggunakan satu atau lebih saklar (switch) untuk merubah dc-dc konverter dari tingkat satu ke tingkatan yang lain. Untuk dc-dc konverter dengan tegangan input yang diketahui sebelumnya, tegangan keluaran rata-rata dikontrol melalui pengaturan durasi yang dibutuhkan untuk saklar on dan off ( $t_{\text {on }}$ dan $t_{\text {off }}$ ). Rangkaian dc-dc ini terbagi menjadi tiga tipe yaitu, rangkaian buck converter (penurun tegangan), rangakain boost converter (penaik tegangan), rangkaian buckboost converter (penaik dan penurun tegangan).

\section{Buck converter}

Buck converter adalah dc-dc converter jenis penurun tegangan atau step down. Konverter ini digunakan untuk mendapatkan tegangan DC yang lebih rendah daripada masukannya [12].

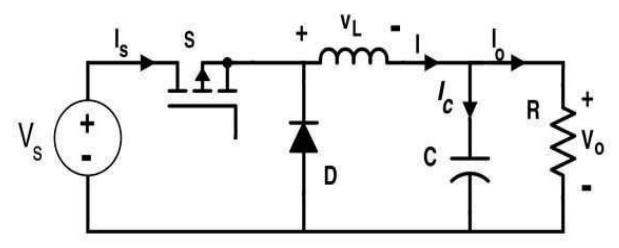

Gambar 1. Skema Rangkaian Buck Converter

Tegangan output Konverter buck ditentukan oleh nilai waktu switching dari sakelar daya konverter buck, waktu switching saklar daya ini diatur dengan metode pulse width modulation (PWM). Nilai duty cycle pulsa modulasi (PWM) sakelar daya konverter menetukan tegangan keluaran konverter buck. Agar tegangan keluaran yang hasilkan sesuai dengan keinginan, maka duty cycle ini harus diatur[12][13]. Sakelar daya yang digunakan konverter buck adalah mosfet. Gambar 2 menunjukan skema konverter buck yang dirancang, Buck converter beroperasi dalam dua kondisi, yaitu ketika saklar tertutup dan ketika saklar terbuka [14].

Pada saat saklar tertutup, diode berada dalam kondisi reverse-biased, saklar mengalirkan arus dari sumber tegangan menuju induktor, kemudian melalui kapasitor dan beban, lalu kembali ke sumber. Pada saat saklar terbuka, diode berada dalam kondisi forwardbiased, arus yang tersimpan pada induktor mengalir ke beban, kemudian menuju diode freewheeling, lalu kembali ke induktor [15].

Hubungan tegangan output converter buck dengan duty cycle ditunjukkan dengan rumus:

$$
\begin{aligned}
& D=\frac{V_{\text {out }}}{V_{\text {in }}} V i n \\
& \text { Keterangan: } \\
& \text { Vin = Tegangan sumber (volt) } \\
& \mathrm{D}=\text { Duty ratio } \\
& \text { Vo = Tegangan keluaran (Volt) }
\end{aligned}
$$

Pada penerapannya DC Chopper bisa memungkinkan suatu sumber penghasil tegangan searah seperti baterai dapat dirubah keluarannya menjadi lebih besar agar bisa dimanfaatkan untuk berbagai perangkat elektronika sesuai kebutuhan[16]. Pada persamaan (1) di tunjukkan bahwa tegangan output konverter buck berbanding lurus dengan nilai duty cycle. peningkatan nilai duty cycle yang diberikan membuat tegangan yang dikeluarkan semakin besar. Duty cycle ini yang akan memodulasi sakelar daya konverter.

\section{a. Pengertian PWM}

\section{Teknik PWM}

PWM adalah suatu teknik modulasi yang mengubah lebar pulsa (pulse width) dengan nilai frekuensi dan amplitudo yang tetap. PWM atau Pulse Width Modulation ini digunakan menghasilkan sinyal 
analog dari perangkat Digital (contohnya dari Mikrokontroller). Untuk sinyal PWM, kita perlu melihat dua parameter penting yang terkait dengannya yaitu Siklus Kerja PWM (PWM Duty Cycle) dan Frekuensi PWM (PWM Frequency).

b. Siklus Kerja PWM (PWM Duty Cycle)

Sinyal PWM akan tetap ON untuk waktu tertentu dan kemudian terhenti atau OFF selama sisa periodenya. Yang membuat PWM ini istimewa dan lebih bermanfaat adalah kita dapat menetapkan berapa lama kondisi $O N$ harus bertahan dengan cara mengendalikan siklus kerja atau Duty Cycle PWM. Rumus untuk menghitung siklus kerja atau duty cycle dapat ditunjukkan seperti persamaan di bawah ini. Duty Cycle $=\mathrm{t} O N /(\mathrm{tON}+\mathrm{t} O F F)$

\section{Atau}

Duty Cycle $=\mathrm{t} O \mathrm{~N} / \mathrm{ttotal}$

Dimana:

tON = Waktu $O N$ atau Waktu dimana tegangan keluaran berada pada posisi tinggi (high atau 1)

tOFF = Waktu $O F F$ atau Waktu dimana tegangan keluaran berada pada posisi rendah (low atau 0 )

ttotal = Waktu satu siklus atau penjumlahan antara tON dengan tOFF atau disebut juga dengan "periode satu gelombang".

\section{ARDUINO UNO}

Arduino adalah suatu minimum sistem yang menggunakan IC dari keluarga AVR dan bersifat open source dengan nama produk arduino. Arduino menggunakan bahasa pemrograman sendiri yang menyerupai bahasa C. Arduino uno mengandung mikroprosesor (berupa Atmel AVR) dan dilengkapi dengan oscillator $16 \mathrm{MHz}$ (yang memungkinkan operasi berbasis waktu dilaksanakan dengan tepat), dan regulator (pembangkit tegangan) 5 Volt. Sejumlah pin tersedia di papan. Pin 0 hingga 13 digunakan untuk isyarat digital, yang hanya bernilai 0 atau 1 . Pin A0-A5 digunakan untuk isyarat analog. Arduino uno dilengkapi dengan static random access memory (SRAM) berukuran $2 \mathrm{~KB}$ untuk memegang data, flash memory berukuran $32 \mathrm{~KB}$, dan erasable programmable read only memory (EEPROM) untuk menyimpan program.
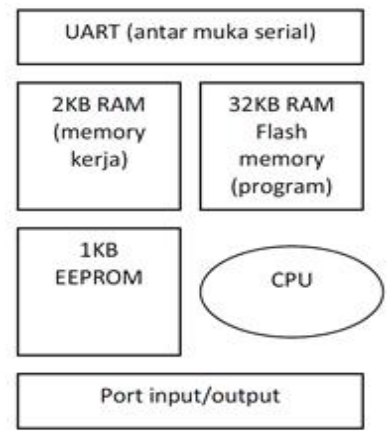

Gambar 3. Blok Diagram Mikrokontroller
Arduino yang digunakan dalam Tugas Akhir ini adalah Arduino Uno. Arduino uno adalah salah satu produk berlabel arduino yang sebenarnya adalah suatu papan elektronik yang mengandung mikrokontroler ATmega328 (sebuah keping yang secara fungsional bertindak seperti sebuah komputer).

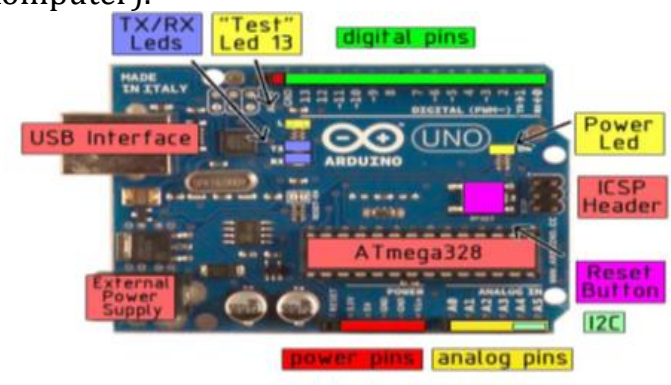

Gambar 4. Modul Arduino Uno

Spesifikasi pada Arduino Uno adalah sebagai berikut:

1. Mikrokontroler : ATmega328

2 Tegangan Operasi : $5 \mathrm{~V}$

3. Tegangan Input (rekomendasi) : $7-12 \mathrm{~V}$

4. Tegangan Input (batas) : 6-20 V

5. Pin digital I/O : 14 (6 diantaranya pin PWM)

6. Pin Analog input :6

7. Arus DC per pin I/O : $40 \mathrm{~mA}$

8. Arus DC untuk pin $3.3 \mathrm{~V}: 150 \mathrm{~mA}$

9. Flash Memory: $32 \mathrm{~KB}$ dengan $0.5 \mathrm{~KB}$ digunakan untuk bootloader

10. SRAM : $2 \mathrm{~KB}$

11. EEPROM : $1 \mathrm{~KB}$

12. Kecepatan Pewaktuan : $16 \mathrm{Mhz}$

\section{Sensor Tegangan (ZMBPT101B)}

Modul sensor tegangan ZMBPT101Badalah sensor tegangan yang terdiri dari transformer ZMPT101B. Modul ini memiliki akurasi yang sangat tinggi, dan konsisten yang baik dalam mengukur sumber tegangan hingga 250V AC. Output ADC diatur menggunakan trimpot untuk menyesuaikan nilai terhadap referensi input[17].

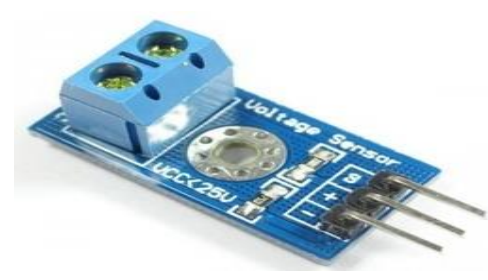

Gambar 5. ZMPT101B voltage sensor module

Rangkaian pembagi tegangan biasanya digunakan untuk membuat suatu tegangan referensi dari sumber tegangan yang lebih besar. Tegangan masukan ke sensor tegangan akan dikonversikan dalam tegangan yang dapat dibaca mikrokontroller yaitu nol sampai lima volt. Lalu 
tegangan akan diterjemahkan menjadi satuan digital melalui mikrokontroller agar dapat diatur lebih lanjut.

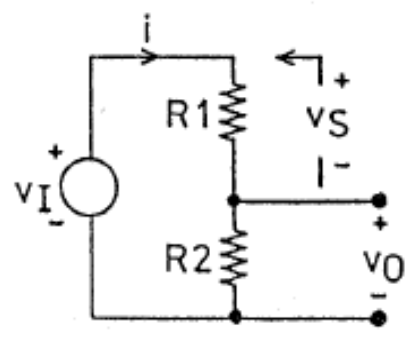

Gambar 6. Rangkaian pembagi tegangan

Rangkaian pembagi tegangan pada gambar diatas dapat dirumuskan sebagai berikut:

$$
V_{0}=V_{i n} \frac{R 2}{R 1+R 2}
$$

Dimana Vo adalah tegangan output, Vin merupakan tegangan input, dan R merupakan beban.

\section{Blok Diagram}

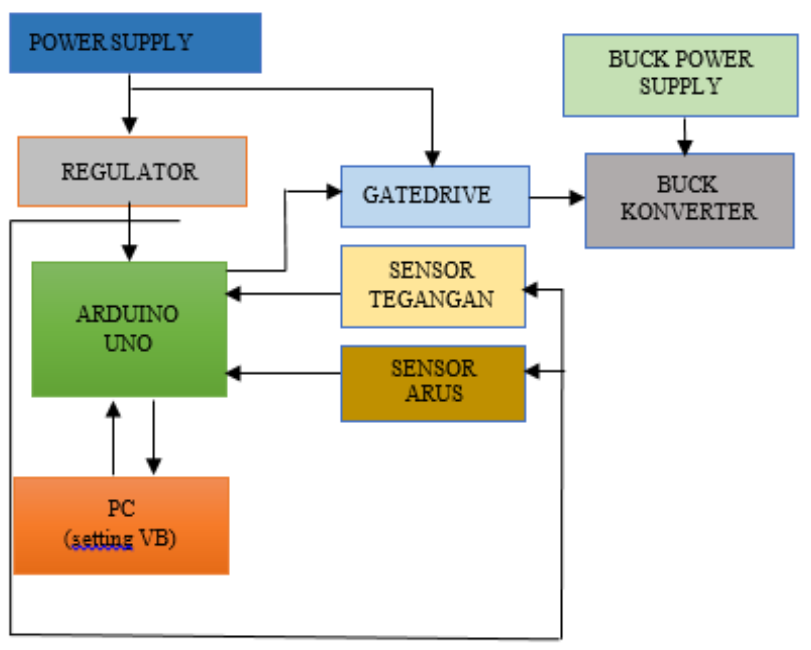

Gambar 7. Blok diagram

Berikut adalah penjelasan dari blok diagram sistem:

a. Pada system ini menggunakan power supply yang memberikan tegangan pada serangkaian sistem, yaitu:

1. Tegangan 220 VAC yang keluar dari power supply akan diturunkan tegangannya dengan trafo step down menjadi 12 VDC.Power supply dengan output 12 VDC akan mensupply rangkaian Arduino Uno.Untuk sensor tegangan dan gate drive menggunakan 5 VDC dari power supply.

2. Pada 5 VDC power supply akan masuk kerangkaian gate drive yang dimana input tegangan dari gate drive ini yaitu, 5 VDC. Dan output tegangan pada gate drive akan menghasilkan tegangan 13 VDC - 15 VDC.

b. Buck Converter berfungsi untuk penurun tegangan input 24 VDC bisa diturunkan sampai 1.2 VDC. Converter ini juga di atur oleh arduino uno melalui rangkaian gate drive dengan mengatur teganganya.

c. Sensor Tegangan berfungsi mendeteksi tegangan dari output Buck Converter. d. Arduino Uno adalah bagian yang berfungsi mengatur system mulai dari penerimaan data sensor dan pengiriman data ke PC.

e. PC (porsonal computer) adalah bagian yang berfungsi sebagai monitor untuk mengontrol besar duty cycle dan melihat berapa nilai tegangan keluaran maupun tegangan masukan pada rangkaian buck converter.

Prinsip kerja sstem secara garis besar yaitu data analog yang didapat dari sensor kemudian diteruskan ke arduino uno untuk pengolahan serta pengiriman ke komputer melalui kabel USB. Pada alat ini dibuat sebuah buck converter yang gunanya untuk menurunkan tegangan keluaran berdasarkan nilai yang kita inginkan, penurunan nilai tegangan dilakukan dengan cara merubah nilai duty cycle yang kita berikan terhadap pin Gate mosfet, perubahan duty cycle tersebut dirubah sesuai dengan nilai yang kita inputkan pada mikrokontroler Arduino dengan menggunakan interface darisebuah PC (personal computer). Interface ini dapat mengontrol besar duty cycle dan dapat meilhat berapa nilai tegangan keluaran maupun tegangan masukan pada rangkaian buck converter. Berikut prinsip kerja sistem monitoring:

a. Data pengukuran kecepatan melalui sensor berupa analog akan dikirim ke port ADC mikrokontroller sesuai dengan urutan yang telah ditentukan.

b. Data analog yang telah diterima Arduino Uno akan diolah dan dikonversikan menjadi data digital dengan memanfaatkan fitur ADC Arduino Uno, Pengolahan tidak perlu menggunakan rangkaian ADC tambahan.

c. Proses pengolahan data yang diterima dari sensor melalui Arduino Uno dengan menggunakan bahasa pemograman Arduino IDE (Intergrated Development Editor). IDE yaitu suatu editor yang kita tinggal mengetik dan menjalankannya saja. Hal ini mencakup penyesuaian rumusan sensor sehingga mampu menyamai atau mendekati nilai dari alat ukur sebenarnya dan pengaturan jumlah data yang akan dikirim ke computer serta set inisialisasi untuk proses hand-shaking data dengan komputer. Hand-shaking adalah suatu proses otomatisasi yang terjadi ketika computer berkomunikasi dengan perangkat asing (arduinouno) untuk menetapkan peraturan untuk komunikasi dan juga sebagai pelengkap dari hand shaking yaitu dikenal juga istilah baudrate. Baudrate mengindikasikan berapa kecepatan data yang dikirim melalui komunikasi serial (USB). Baudrate diberi satuan bit-per second (bps). Proses monitoring data akan kontiniu dan berulang sampai batas waktu yang ditentukan dalam pengambilan data. 


\section{Flowchart}

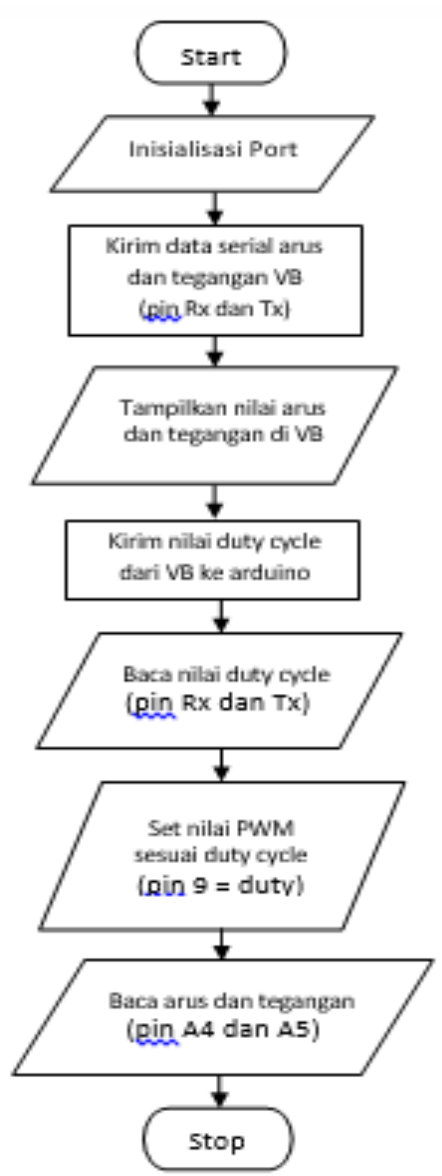

Gambar 8. Flowchart Program

\section{Perancangan Rangkaian Keseluruhan}

Pada rangkaian keseluruhan memperlihatkan semua rangkaian-rangkaian yang digunakan pada Sistem Pegendalian Motor DC menggunakan buck converter berbasis Arduino Uno. Bentuk rangkaian keseluruhan seperti yang terlihat pada Gambar 9 .

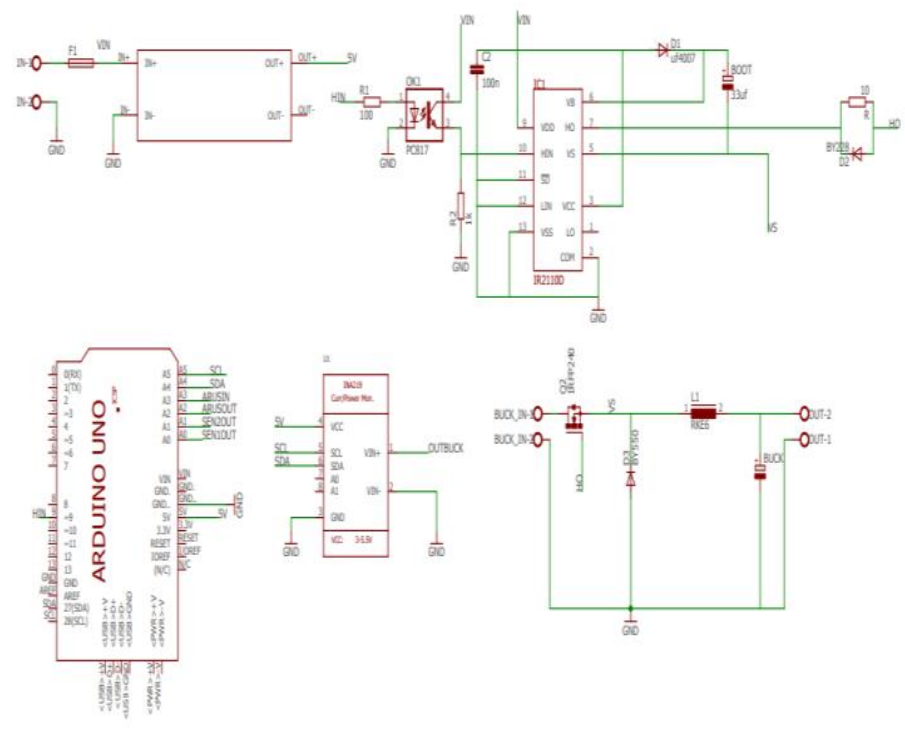

Gambar 9. Rangkaian Keseluruhan Buck Converter

\section{HASIL DAN PEMBAHASAN}

Berdasarkan pengujian rangkaian yang dilakukan, berikut data yang diperoleh dari hasil pengujian rangkaian keseluruhan.

TAMPILAN PADA VB

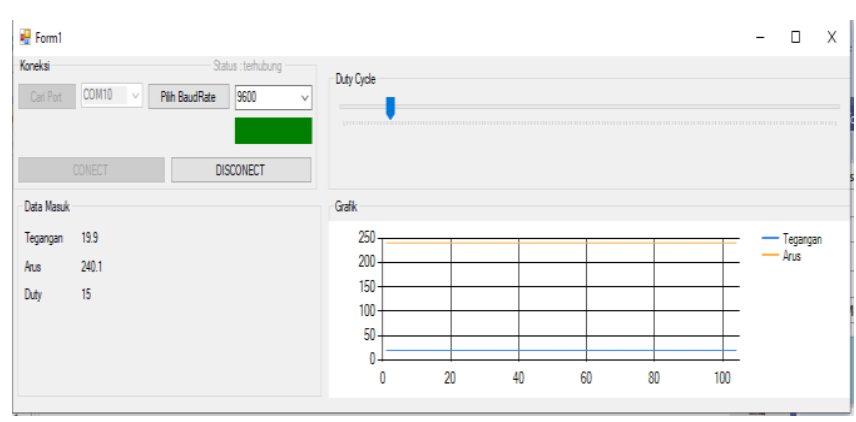

Gambar 10. Tampilan VB

Gambar 10 tersebut menunjukkan tampilan VB dengan merubahan slide bar, maka duty cycle berubah dan PWM yang dikirimkan ke arduino-pun berubah. Berikut tampilan PWM yang telah di setting melalui VB yang ditampilkan di osiloscop.

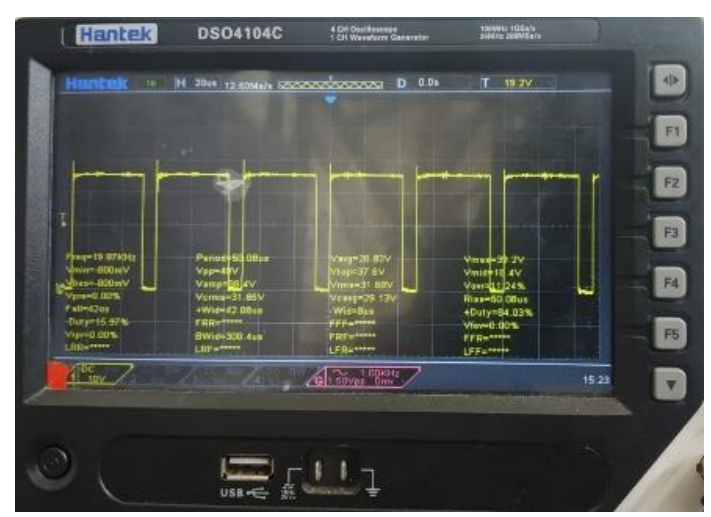


Gambar 11. Grafik gelombang PWM untuk tegangan 19.9 volt

Pulsa PWM yang dihasilkan pin PWM Arduino seperti ditunjukan oleh Gambar 11 diatas telah sukses menghasilkan tegangan ouput sebesar 19.5 Volt. Nilai tersebut sudah mendekati tegangan output referensi sebesar 19.9 volt yang di set dengan VB.

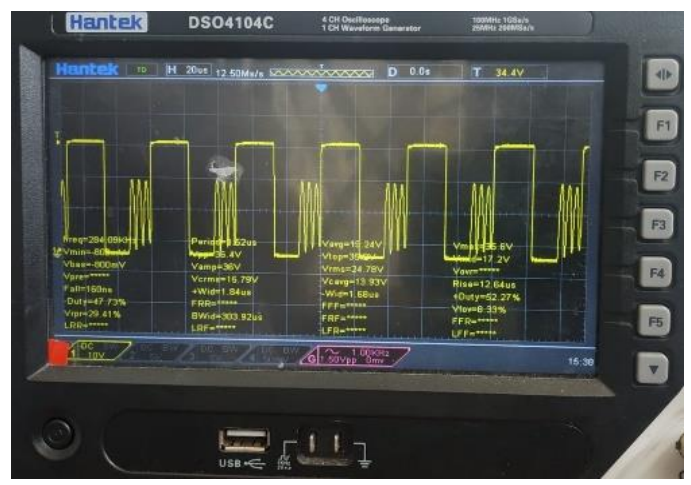

Gambar 12. Grafik gelombang PWM untuk tegangan 14.2 volt

Pulsa PWM yang dihasilkan pin PWM Arduino seperti ditunjukan oleh Gambar 12 diatas telah sukses menghasilkan tegangan ouput sebesar 14 Volt. Nilai tersebut sudah mendekati tegangan output referensi sebesar 14.2 volt yang di set dengan VB.

TABEL 1. HASIL PENGUJIAN

\begin{tabular}{|c|c|c|c|c|c|c|c|}
\hline NO. & $\begin{array}{c}\mathbf{V}_{\text {in }} \\
\text { (Volt) }\end{array}$ & $\begin{array}{c}\mathbf{R} \\
\mathbf{( 0 h m )}\end{array}$ & $\begin{array}{c}\mathbf{V}_{\text {out }} \\
\text { (Volt) }\end{array}$ & $\begin{array}{c}\mathbf{V}_{\text {VB }} \\
\text { (Volt) }\end{array}$ & $\begin{array}{c}\mathbf{I}_{\text {out }} \\
\text { (Amper) }\end{array}$ & $\begin{array}{c}\mathbf{I}_{\text {VB }} \\
\text { (Amp } \\
\text { er) }\end{array}$ & $\begin{array}{c}\text { Duty } \\
\text { Cycle } \\
\text { (\%) }\end{array}$ \\
\hline $\mathbf{1}$ & 24 & 80 & 19.5 & 19.9 & 230 & 205.5 & 15.97 \\
\hline $\mathbf{2}$ & 24 & 100 & 19.5 & 19.8 & 190 & 206.7 & 15.97 \\
\hline $\mathbf{3}$ & 24 & 150 & 19.5 & 19.9 & 130 & 205 & 15.65 \\
\hline $\mathbf{4}$ & 24 & 200 & 19.5 & 19.9 & 100 & 205 & 15.97 \\
\hline $\mathbf{5}$ & 24 & 250 & 19.8 & 20 & 80 & 206 & 15.81 \\
\hline $\mathbf{6}$ & 24 & 300 & 19.8 & 19.8 & 70 & 204 & 15.81 \\
\hline $\mathbf{7}$ & 24 & 320 & 19.8 & 19.8 & 60 & 204 & 16.61 \\
\hline $\mathbf{8}$ & 24 & 320 & 14 & 14.2 & 40 & 149 & 16.45 \\
\hline $\mathbf{9}$ & 24 & 300 & 14 & 14.2 & 50 & 149.2 & 34.57 \\
\hline $\mathbf{1}$ & 24 & 250 & 14 & 14.2 & 60 & 149.2 & 47.73 \\
$\mathbf{0}$ & & & & & & & \\
\hline $\mathbf{1}$ & 24 & 200 & 13.9 & 14.2 & 70 & 149.2 & 34.57 \\
\hline $\mathbf{1}$ & & & & & & & \\
\hline $\mathbf{1}$ & 24 & 150 & 13.6 & 14.2 & 90 & 147.3 & 34.42 \\
\hline $\mathbf{2}$ & & & & & & & \\
\hline $\mathbf{1}$ & 24 & 80 & 13.5 & 14.2 & 165 & 147.4 & 31.25 \\
\hline $\mathbf{3}$ & & & & & & & \\
\hline & & & & & & & \\
\hline
\end{tabular}

Berdasarkan hasil pengujian pada table di atas, maka dapat dilihat dalam bentuk grafik sebagai berikut.

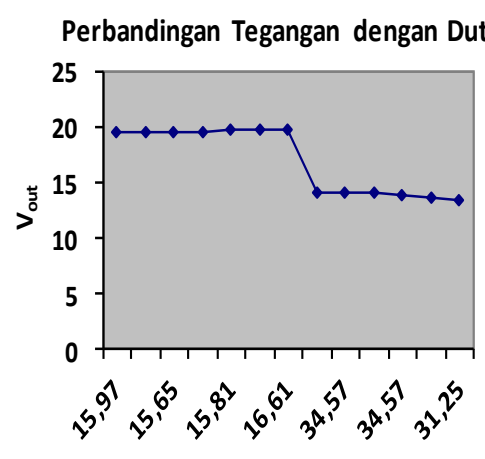

Duty cycle

Gambar 12. Kurva Perbandingan Tegangan dengan Duty cycle

Grafik pada Gambar 12 menunjukkan hubungan antara duty cycle (axis $\mathrm{x}$ ) dan tegangan (axis y). Dapat disimpulkan bahwa semakin besar duty cycle yang diberikan maka tegangan keluaran akan semakin kecil.

\section{Grafik Perbandingan Beban dengan Arus}

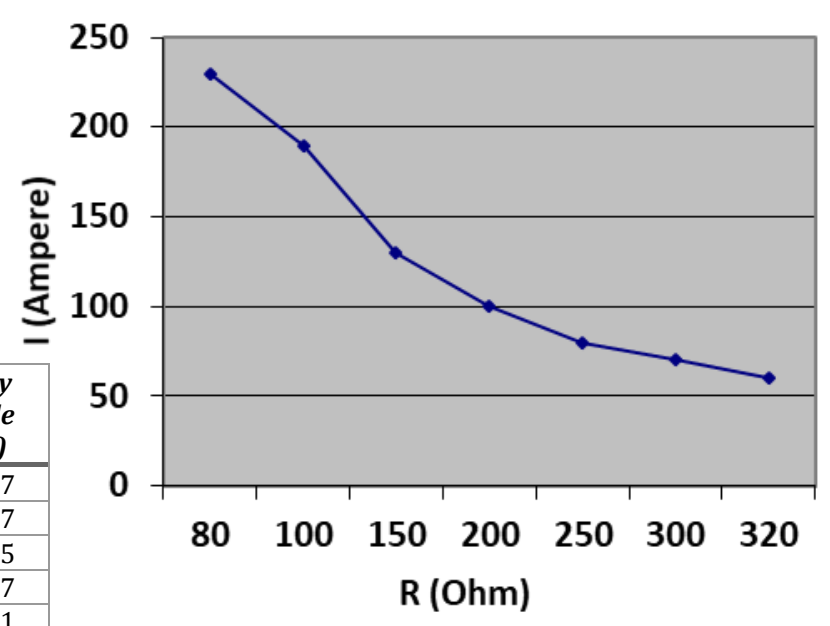

Gambar 12. Grafik Arus pada Vo 19 Volt

Grafik Perbandingan Beban dengan Arus

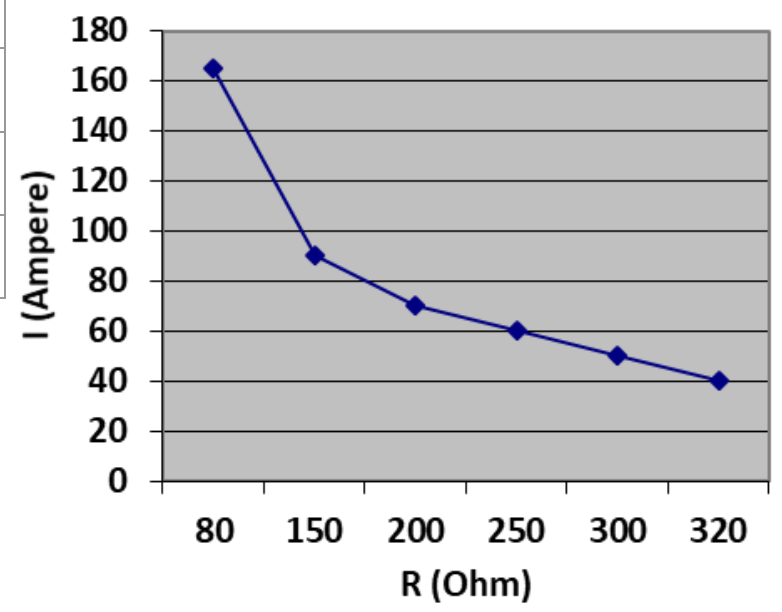

Gambar 13. Grafik arus pada Vo 14 Volt 
Pengujian rangkaian buck converter ini menggunakan tegangan input 24 volt dari power supply dengan duty cycle yang berubah-ubah dan hasil tegangan keluaran yang berbeda juga. Berdasarkan pengujian yang telah dilakukan, semakin tinggi duty cycle maka nilai tegangan keluaran akan semakin kecil. Perubahan nilai duty cycle juga akan mempengaruhi bentuk gelombang keluaran pada oscilloscop. Arus keluaran pada buck converter tergantung pada beban yang diberikan. Dapat dilihat pada Gambar 12 dan Gambar 13 yang merupakan hubungan antara perubahan nilai beban (axis x) dan perubahan nilai arus keluaran (axis y). Hal tersebut menunjukkan semakin besar beban yang diberikan maka arus keluaran yang didapatkan akan semakin kecil juga.

\section{PENUTUP}

Berdasarkan hasil pengujian buck converter, dengan menggunakan Visual Basic sebagai interfacing dapat berjalan dengan baik. Hal ini dapat dilihat dari perubahan nilai duty cycle yang diberikan dapat merubah tegangan keluaran buck converter. Dengan selisih error yang terbaca pada visual basic dan multimeter sebesar 0.4 volt.

\section{REFERENSI}

[1] Aswardi, M. Yuhendri dan DTP. Yanto, Teknik Elektronika Daya, Indonesia : IRDH Book Publisher, 2020.

[2] Rashid, Muhammad H. 2011. "Power Electronics Handbook Third Edition". Elsevier's Science and Technology Department. Oxford. UK.

[3] Pramudifta. Andana, "Perancangan PWM Digital Konverter Boost Menggunakan Mikrokontroler Atmega8535",Universitas Negeri Padang, Padang, 2018.

[4] D.W. Hart, Power Electronics, New York, USA: McGraw-Hill, 2010.

[5] Peeyush and V.Chaurasia, "Design and Implementation of Boost Converter for IoT Application," Int. Journal of Innovative Research in Science, Engineering and Technology (IJIRSET), vol. 6, no. 6, June 2017.

[6] M. Cucuzzella, R. Lazzari, S. Trip, S. Rosti, C. Sandroni and A. Ferrara, "Sliding mode voltage control of boost converters in DC microgrids," Control Engineering Practice, vol. 73, pp. 161-170, April 2018.

[7] V. Viswanatha and R.V.S. Reddy, "Digital Control of Buck Converter Using Arduino Microcontroller For Low Power Applications", 2017 International Conference On Smart Technologies For Smart Nation (SmartTechCon), pp. 439-443,17-19 Aug 2017.

[8] SP. Armadilla, DN. Syechu, S. Epyk, "Desain dan Simulasi Bidirectional DC-DC Converter untuk Penyimpanan Energi pada Sistem Fotovoltaik", JNTETI, Vol. 9 No. 3, Agustus 2020.
[9] A. S. Werulkar and P.S. Kulkarni. "Design of Constant Current Solar Charge Controller with Microcontroller Based Soft Switching Buck Converter for Solar Home Lighting System", 2012 IEEE International Conference on Power Electronics, Drives and Energy Systems (PEDES 2012), Dec 16-19,2012.

[10] W. W. A. Ramadhan and T. Abuzairi. "Simulation and Analysis of a Buck Converter Based on an Arduino PWM Signal Using a Single Cell Li-Ion Load", 2019 IEEE International Conference on Quality in Research (QIR): International Symposium on Electrical and Computer Engineering, 20-23 June 2019.

[11] M. I. Esario and M. Yuhendri, "Kendali Kecepatan Motor DC Menggunakan DC Chopper Satu Kuadran Berbasis Kontroller PI," JTEV, vol. 06, no. 01, pp. 296- 305, 2020.

[12] H. Kovacevic and Z. Stojanovic, "Buck converter controlled by Arduino Uno", 2016 39th Int. Conv. Inf. Commun. Technol. Electron. Microelectron. MIPRO 2016-Proc., pp. 1638-1642, 2016

[13] H. Matalata and L. W. Johar, "Analisa Buck Converter Dan Boost Converter Pada Perubahan Duty Cycle Pwm Dengan Membandingkan Frekuensi PWM 1, 7 Khz DAN 3, 3 Khz," J. Ilm. Univ. Batanghari Jambi, vol. 18 , no. 1 , pp. $42-50,2018$

[14] A. Aswaldi and M. Yuhendri, "Sitem Kendali Dan Monitoring Boost Converter Berbasis GUI (Graphical User Interface) Matlab Menggunakan Arduino", JTEIN, vol. 1, no 2, pp.266-272, 2020.

[15] Eka Samsul (2019)Apakah itu arduino? Online site: .http://jagootomasi.com/apakah-itu-arduino/ (diakses tanggal: 12 Februari 2021).

[16] Aswardi. 2010. Modul Elektronika Daya. Padang : Teknik Elektro Universitas Negeri Padang., No Title.

[17] Abubakar, dkk. (2017, Februari). Calibration of ZMPT $101 B$ Voltage Sensor Module Using Polynomial Regression For Accurate Load Monitoring. ARPN Journal Vol.12 No. 4.

[18] Frengki, dkk. 2016. "Analisis Steady State dan Dinamik pada Perencanaan Pengembangan Pembangkit Sistem Gorontalo". Jurnal Arus Elektro Indonesia (JAEI) Vol. 2, No. 1, Mei 2016.

\section{Biodata Penulis}

Mohammed Abdul Aziz Al-Haqeem, lahir di Wonosobo, 24 Juli 1995. Menyelesaikan studi DIV Teknik Elektro Industri pada Jurusan Teknik Elektro Fakultas Teknik Universitas Negeri Padang.

Dr. Aswardi, M.T, dilahirkan di Kubang Putih Agam, 21 Februari 1959. S1 Pendidikan Teknik Elektro di Universitas Negeri Padang lulus pada tahun 1983. S2 Pendidikan Teknik Elektro di Institut Teknologi Bandung lulus pada tahun 1999. Staf pengajar pada jurusan Teknik Elektro FT UNP - Sekarang. 